The Chittagong Univ. J. B. Sci., Vol. 6(1 \&2):87-95, 2011.

\title{
A COMPARATIVE STUDY OF VALUES BETWEEN COLLEGE AND MADRASHA STUDENTS OF CHITTAGONG CITY
}

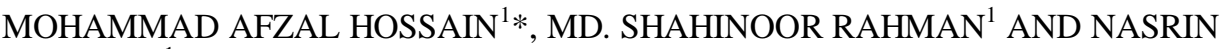 \\ SULTANA ${ }^{1}$ \\ Department of Psychology, University of Chittagong, Chittagong-4331, Bangladesh.
}

\begin{abstract}
The aim of the present study was to investigate the difference between values of College and Madrasha Students of Chittagong city. In order to attain this purpose two groups of respondents, one consisted of 50 college students (Male $=25$, Female $=25$ ) studying in Higher Secondary level and another consisted of 50 Madrasha students (Male $=25$, Female $=25$ ) studying in Alim level were selected. An adapted Bengali version of "Allport-Vernon-Lindzey study of values" was used to measure theoretical, economic, aesthetic, social, political and religious values of these students. The obtained data were subjected to t test. The analysis of results indicated that the value $t$ for theoretical (4.288), aesthetic (2.610) and religious (2.85) values were significant at .05 level but the values of $t$ for economic (1.40), social (0.217) and political (0.49) were not significant. The findings indicated that Madrasha students posses more theoretical \& religious values than college students. While, college students are more aesthetic than Madrasha students. Significant difference does not exist between Madrasha students \& College students in political, economic \& social values.
\end{abstract}

Key words: Values, Madrasha students, College students.

\section{INTRODUCTION:}

The value is considered as comparatively permanent belief which is formed by accumulating several attitudes. Honesty, independence, sincerity etc. are the examples of some values. According to Katz and Stotland (1959) "Attitudes may be organized into consistent \& coherent, structures known as value system."

Values are unique verbal concepts that relate to the worth given to specific kinds of objects, acts \& conditions by individuals and groups. At least 3 dimensions can be found for values-

i. A quantitative element, which indicates the amount of worth one allocates to the particular phenomenon.

"Corresponding author:afzalpsycu@yahoo.com 
ii. A quality of elasticity, which is evidenced by the extent to which a person holds to his ideas.

iii. The interrelationship or system frequently referred to as the individual's hierarchy of values.

We may possess thousands of attitudes but there are few dozens of values (Rokeach 1968). Crutchfield (1955) mentioned that "value is the person's belief toward good or bad."

Values have a great influence on human personality and his overt behavior. Every man has his own value system and it is his personality structure. That is why, some psychologists believe that one's personality can be reliably measured by assessing one's values.

Spranger (1928) described six values and these are

The dominant interest of the theoretical man is the discovery of truth. The interests of the theoretical man are empirical, critical and rational. His aim in life is to order and systematize his knowledge.

The economic man is characteristically interested in useful and practical values. He is interested to embrace the practical affairs of the business world, the production, marketing and consumption of goods, the elaboration of credit and the accumulation of tangible wealth. The economic man wants education to be practical \& regards unapplied knowledge as waste.

The aesthetic man sees his highest value in the form and harmony. Each single experience is judged from the stand point of grace, symmetry or fitness. He regards life as procession events each single impression is employed for its own sake.

The highest value for this type is love for people. He prizes other persons as ends and is therefore himself kind, sympathetic and unselfish. Spranger adds that in its purest form the social interest is selfless and tends to approach very closely to the religious attitude.

The political man is interested primarily in personal power, influence and renown. His activities are not necessarily limited to the narrow field of politics; but whatever his vocation, he betrays himself as a Machtmensch. Leaders in any field generally have high power value. 


\section{A COMPARATIVE STUDY OF VALUES BETWEEN COLLEGE AND MADRASHA}

STUDENTS OF CHITTAGONG CITY

The Religious: The religious man is mystical and is concern with the unity of all experience and seeks to comprehend the cosmos as a whole. He has dominant interest in what is divine in every phenomenon.

Values are the components of personality makeup and are the products of socialization. As social concepts, values are involved in the educative process because they are basic to the society.

The Madrasah education system focuses on religious education and teaching. All the basics of education are in a religious environment, while general education emphasizes secular education. The curriculum in Madrasha includes all areas in Islamic studies and acquisition of greater understanding of Islamic principles that govern day to day lives of the Muslims. Their subjects are as FiqaIslamic law, Hadith-Prophets Saying, Sunna-Prophets traditions, Tafsir and Muslim history etc. Depending on the educational demands some Madrasha also include the courses like Mathematics, History, Geography, Elementary Science and English with Islamic subjects.

The teachings of other subjects are treated as secondary in Madrasha education. But in college education, these are taught as primary subjects. The purpose of Islamic education is to give meaning of life to a person and enriching it with the light of the Islamic faith as outlined in the Quran.

As a consequence it is assumed that the value systems Madrasha students should be different from that of college students. Madrasha students are expected to possess more religious values than college students. Now-a-days both the College and Madrasha students are concerned with the political atmospheres of the world and play active roles in the field of politics. Again both students are concerned with human relationship in the form of love. They are more sympathetic toward the society. Beside social, religious and political value, there are several other values in which the students may differ or not differ. To investigate the differences "Allport-Vernon-Lindzey" Study of Values is a suitable tool.

\section{Literature review}

Social psychologists of different parts of the world have applied the scale to investigate their people's values at different times. Spranger (1928) wrote in his book- 'Types of men' that every person organizes his personality through acknowledging some values. Mohsin (1950) and Chowdhury (1960) in their research found in Indian culture that values were changed in different ages. 
MOHAMMAD AFZAL HOSSAIN et al.

Kelley (1955) based on his 20 year's long investigations concluded that as the individuals grows older his religious values goes high but aesthetic values declines. Zaman (1973) found that values change with the change of time.

The present investigation was undertaken to see whether there is any difference in theoretical, social, economic, aesthetic, political and religious values between College and Madrasha students of Chittagong city.

\section{MATERIALS AND METHODS}

\section{Sample}

The study samples consisted of 50 students $($ Male $=25$, Female $=25$ ) studying at Higher Secondary level in colleges and the other consisted of 50 students $($ Male $=25$, Female $=25)$ studying at Alim level in Madrashas. The students of colleges were incidentally selected from Chittagong University College, Chittagong college and Kolgau college. The Madrasha students were also incidentally selected from Jameia Ahmodia Sunneia Madrasha and Jameia Adhodia Madrasha of Chittagong city. The mean age of the college students was 20 years and that of Madrasha students was also 20 years. The socio-economic status of the students of both categories were more or less similar which ranged from lower to upper middle classes.

\section{Instrument used}

An adapted Bengali version of Allport-Vernon-Lindzey study of values (Zaman 1973) originally developed by Allport et al. (1960) was used for measuring the six basic values. The test consists of a number of questions, based upon a variety of familiar situations to which two alternatives answers in part I and four alternatives in part II are provided. Part- I consists of 30 questions and part II consists of 15 questions. There are two alternative answers for each question in Part-I and four alternative answers in Part-II. In Part-I the task of the respondent is to give a score of 2 to the more preferable answers and a score of 1 to the less preferable answers. If any answer is not preferable at all, she/he is to give it a score of 'o' and its alternative a score of 3 . In part- II, the task of the respondent is to give a score of 4 to the $1^{\text {st }}$ choices, a score 3 to the $2^{\text {nd }}$ choices, a score of 2 to the $3^{\text {rd }}$ choices and a score of 1 to the $4^{\text {th }}$ choice. 
A COMPARATIVE STUDY OF VALUES BETWEEN COLLEGE AND MADRASHA STUDENTS OF CHITTAGONG CITY

\section{Scoring}

The scoring of the test has several steps, but as a whole, the scoring process is not at all any complex one. The steps are as follows:

i. First, it is ensured whether the subject has escaped any item, 1.5 Mark is distributed of the first part and $21 / 2$ mark are distributed to the $2^{\text {nd }}$ part. The distribution is done by the researcher. But it is recommended that the researcher will ensure that the respondents have given all answers.

ii. When the answer sheet is prepared for calculation the given answers are added vertically to each other and the cumulative score for each individual column is written down in the particular box, at the bottom of the pages. There are six boxes in each page, which are assigned as R,S,T,X,Y, and Z. The order of these boxes are not the same in every page.

iii. The next step of scoring is to sum up the scores according to the relevant boxes like $\mathrm{X}$ or $\mathrm{Y}$ or $\mathrm{Z}$ etc. Each box represent each individual value. All these calculation take place in the supplied data calculation sheet.

iv. Then some correction figures is summed ( +/- ) up with the obtained scores for six values. It is also checked whether the grand total is 240 . At last, the six final scores are plotted on the vertical lines on the back of the score sheet and joined together by lines.

\section{Procedure}

To measure the values of the college students first of all they were selected at incidentally from Chittagong University College, then Chittagong College and Kolgau city Corporation College. The scale was administered individually on the students. The students were informed that it is a part of a research and the information gathered from them would be kept confidential. The booklets were distributed to the students and they were asked to go carefully through the instructions printed on the cover page of the booklet. The students were asked to answer all the questions and all clarification were given related to possible difficulties in understanding the instruction. After completion of the testing session the booklets were collected from the respondents and they were given thanks for their since co-operation. There was no time limit. However, most students required about 30 minutes to answer all the questions of the test. The same procedure was followed in collecting data from the students of the Madrasha. After completion of data collection, scoring of the responses were done following the procedure provided in the manual of the test. Two set of scores were obtained one set for college students and another set for Madrasha students. 
MOHAMMAD AFZAL HOSSAIN et al.

\section{RESULTS AND DISCUSSION}

After successfully calculating the data, $\mathrm{t}$ test was applied to assess the significance level of the results. Result revealed significant difference between the two groups of students related to their values. The result is presented Table 1

TABLE 1. MEAN AND SD OF DIFFERENT VALUES OF COLLEGE AND MADRASHA STUDENTS WITH t-VALUE.

\begin{tabular}{lccccc}
\hline Value type & \multicolumn{2}{c}{ College } & \multicolumn{2}{c}{ Madrasha } & \multirow{2}{*}{ T } \\
\cline { 2 - 5 } & $\bar{X}$ & SD & $\bar{X}$ & SD & T \\
\hline Theoretical & 43.62 & 3.784 & 47.6 & 5.410 & $4.288^{*}$ \\
Economic & 37.84 & 4.995 & 36.34 & 5.595 & 1.40 \\
Aesthetic & 35.14 & 5.855 & 31.94 & 6.275 & $2.610^{*}$ \\
Social & 44.44 & 5.5471 & 42.72 & 6.690 & 0.217 \\
Political & 38.46 & 4.46 & 38.84 & 3.06 & 0.49 \\
Religious & 40.12 & 6.86 & 42.92 & 4.214 & $2.85^{*}$ \\
\hline
\end{tabular}

The figure in the above table (table1) indicate that the value of $t$ for theoretical value (4.288), aesthetic (2.610) and religious (2.85) values were significant at 0.05 level but the values of $t$ for economic (1.40), social (0.217) and political (0.49) values were not significant. The result indicates that madrasha students are more theoretical and religious than college students. While college students are more aesthetic than madrasha students. No significant difference exist in economic, social and political values between College and Madrasha student.

The purpose of the study was to measure values of College and Madrasha students. Data were collected from two incidentally selected and compare the samples, the college students and the Madrasha students. To calculate the data $t$ test were applied to assess the level of significance. The analysis of results revealed that the mean theoretical value score of Madrasha students $(\bar{X}=47.6)$ was significantly greater than that of college students $(\bar{X}=43.62)$. This result can be explained in the way that Madrahsa students have more dominant interest 
A COMPARATIVE STUDY OF VALUES BETWEEN COLLEGE AND MADRASHA STUDENTS OF CHITTAGONG CITY

in the discovery of truth than college students. Madrasha students characteristically take a more cognitive attitude that divests itself of judgment regarding the beauty or utility of objects and seeks only to observe and to reason than college students.

Result of economic value reveled that no significant difference existed between the mean. The score of college students $(\bar{X}=37.84)$ was greater than that of Madrasha students $(\bar{X}=36.34)$. This result interpreted that both the college and madrasha students are interested in wealth. Their intentions are more to embrace the practical affairs to the business world, the production, marketing and consumption of goods and the accumulation of tangible wealth.

In case of aesthetic value, the mean score of college students $(\bar{X}=35.14)$ was significantly greater than that of Madrasha students $(\bar{X}=31.94)$. This result can be explained in the way that college students have more interest in aesthetic value than the madrasha students. They maintain the highest value in form and harmony, judged from the standpoint of grace, symmetry or fitness. Their main interest is in the aesthetic episodes of life.

Results of social value revealed that no significant difference existed between the mean score of the college students $(\bar{X}=44.44)$ and that of the madrasha students $(\bar{X}=42.72)$. It can be said that students of both groups are equally sympathetic to the people of the society. They regard love as it is the only suitable form of human relationship.

The analysis of political value score reveal that no significant difference was found between the mean score of college students $(\bar{X}=38.46)$ and that of Madrasha students $(\bar{X}=38.84)$. Here it can be said that, the students of both groups are more interested in personal power, influence and renown. Since competition and struggle play a large part more in the life of the college students as well as among the Madrasha students.

In case of religious value, Madrasha students yielded greater mean score $(\bar{X}=42.92)$ than college students $(\bar{X}=40.12)$. This finding can be interpreted that the Madrasha students possess dominant interest in what is divine in every event compare to the college students. They are more mystical and seek to comprehend the cosmos as a whole. 
MOHAMMAD AFZAL HOSSAIN et al.

Finally it can be said that, difference exists in three basic areas of value such as theoretical, aesthetic and religious between college and madrasha students. The other three areas of value such as economic, social and political no significant differences exist. College students are more aesthetic than Madrasha students. While Madrasha students are more theoretical and religious than college students.

The differences in the value system between College and Madrasha students are not significantly greater. More research needs to be carried out into the other possible factors that could explain the difference between College and Madrasha students in the value system.

\section{REFERENCES}

ALLPORT, G.W., VERNON,P.E AND LINDZEY,A.G.1960. Study of values : A Scale for Measuring the Dominant Interests in Personality. Manual, Houghton Company, Boston. pp. 2-19.

CHOWDHURY, R. K. 1958. Indian Modification of Allport-Vernon Study of Values. Indian Psychology, 1960. In: Education System-Linked Differences in Basic Area of Value System by Karim, R, and Rahman, H., The Dhaka University Journal of Psychology 25: 58.

CRUTCHFIELD, R.S. 1955. Conformity and Character. American Psychologist 10: $191-198$.

KATZ, D. AND STOTLAND, E. A.1959. Preliminary statement to a theory of attitude structure and change, In: Koch, S. (Ed.), Psychology: A Study of Science. New York, McGraw-Hill 3: 423-475.

KELLY,E.L.1955. Consistency of the Adult Personality. American Journal of Psychology. 16: 659-681.

MOHSIN, S.1950. Allport-Vernon Study of Values in Indian Situation. Relegious Group Difference in Values. In: Education System-Linked Differences in Basic Area of Value System by Karim, R, and Rahman, H., The Dhaka University Journal of Psychology 25: 58.

ROKEACH, M. 1968. Beliefs, Attitudes and Values, San Francisco: Jossey-Bass. pp.113. 
A COMPARATIVE STUDY OF VALUES BETWEEN COLLEGE AND MADRASHA STUDENTS OF CHITTAGONG CITY

SPRANGER, EDUARD.1928. Types of men: the psychology and ethics of personality, Translated from $5^{\text {th }}$ German ed. by Paul, P.W. American agent: Stechert-Hafner, Inc, New York In: Study of values : A Scale for Measuring the Dominant Interests in Personality by Allport,G.W.,Vernon,P.E and Lindzey,A.G.1960. Manual, Houghton Company, Boston. pp. 4-5.

ZAMAN, S. S. 1973. Changes in Values, Dhaka University Studies. XXI (Part-A): 149-163.

Manuscript received on 22.12.2011; Accepted on 07.07.2012

The Chittagong University Journal of Biological Sciences, Vol. $6(1 \& 2)$. Page No. 